\title{
20. 沖縄地方の赤土流出抑制に向けた流域経営システムの可能性に関する研究 THE POSSIBILITY OF WATERSHED MANAGEMENT FOR CONTROL OF THE SOIL DISCHARGE AND PRESERVATION OF THE CORAL REEF IN OKINAWA DISTRICT
}

\author{
宮本善和 $*$ ・成瀬研治 $*$ ・松下潤**・惠小百合 $* * *$
}

Yoshikazu Miyamoto*, Kenji Naruse*, Jyun Mtsushita**, Sayuri Megumi***

\begin{abstract}
The soil erosion at farmland becomes serious impact on the ecosystem in the coral reef in Okinawa district. In order to solve these problems, it is necessary to build a support system for the integration of the measures in a river basin. This paper examines the possibility of watershed management for the support system as follows, 1) the possibility of watershed management in Ishigaki Island, 2) the evaluation of elements of the fund system for preservation of coral reef, 3) the approach of proposal and embodiment of the study for watershed management.
\end{abstract}

KEYWORDS : watershed management, fund system, coral reef, soil erosion, collaboration

\section{1 はじめに}

沖縄地方では、近年、陸域からの赤土土袞や污水等の流出が顕著になり、沿岸域の污染によってサンゴ礁 の生態系の劣化が重大な問題となっている。沖縄県は 1994 年に「赤土等流出防止条例」を制定したが、現在 の赤土の主要な発生面源である農耕地での具体的な規制や対策は不十分である。加えて、沖縄における農業 は零細で、経営基盤が弱く、対策まで考慮した営農活動を自発的に行うことは非常に困難である。

このような問題を解決するため、著者らは、大澤ら ${ }^{1)}$ が石垣島名蔵川流域で研究を進めている「流域規模 におけるハード対策の統合化」を補完・促進するためのソフト対策として、地域の農業形態の転換を支援す るための環境保全型の流域経営システムを構築することを目的として研究を展開している。既に、著者ら ${ }^{2)}$

は、石垣島の流域を対象と して、環境保全型の流域経 営システムのイメージを提 示する（図-1）とともに、 そのシステムを資金面から 支援するための基金制度の あり方と課題について事例 分析から明らかにした ${ }^{2)}$ 。

そして、その流域経営シ ステムと基金制度の構成、 可能性について、政策提言、 政策実現に向け学際的な研 究を進めている。本稿は、 このような研究の中から、 (1)石垣島における流域経 営の可能性、(2)基金制度の 構成要素と評価、(3)政策提 言・実現のための取組みに ついて報告する。

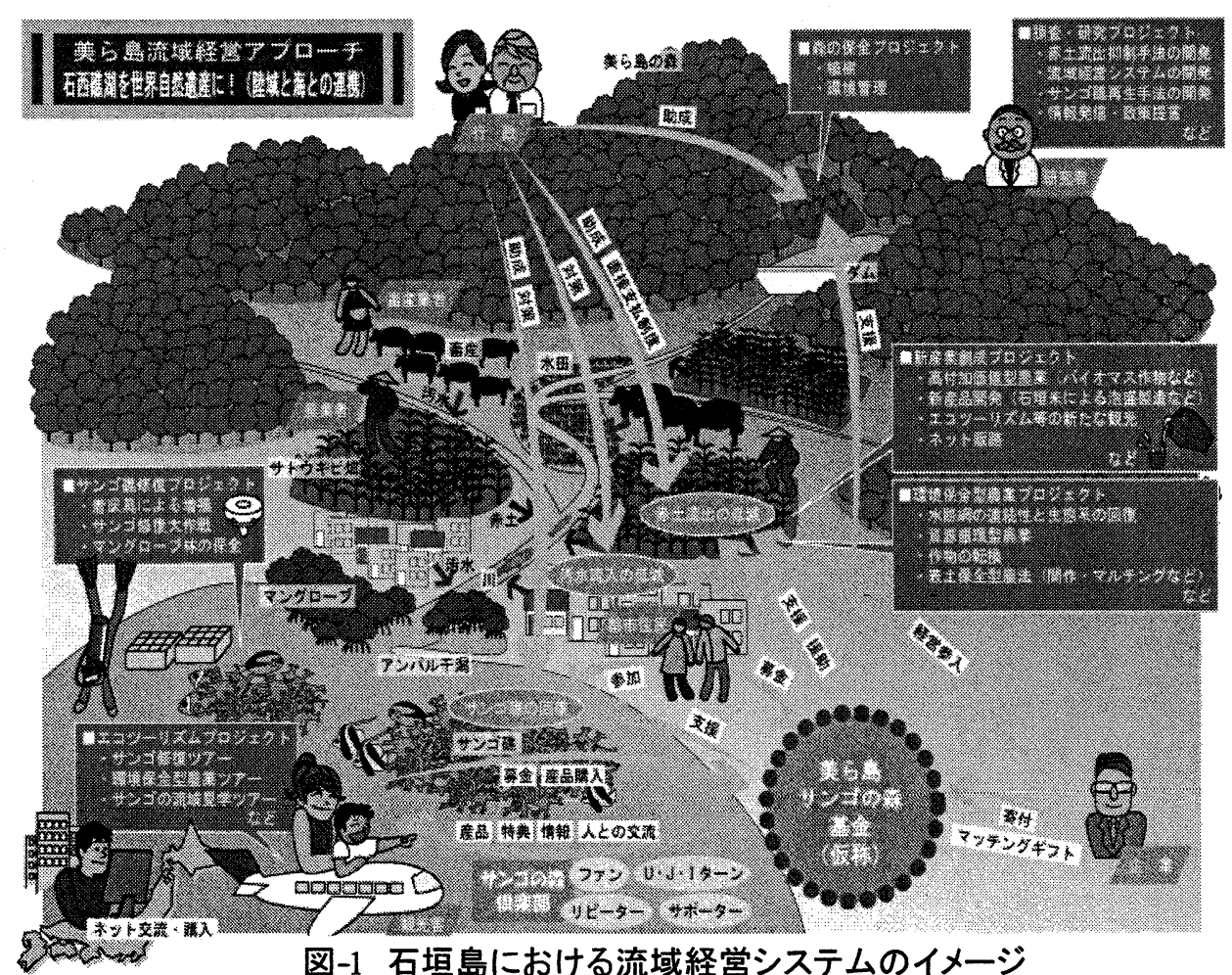

図-1 石垣島における流域経営システムのイメージ

*中央開発株式会社 環境·防災事業部 Department of Environmental Planning and Disaster Prevention, Chuo Kaihatsu Corporation. **芝浦工業大学 システム工学部 Department of Systems Engineering, Shibaura Institute of Technology.

***江戸川大学 環境デザイン学科 Department of Environmental Design, Edogawa University. 


\section{2 石垣島における流域経営システムの可能性}

著者ら ${ }^{2)}$ は、世界的にも貴重な沖縄県八重山地方のサンゴ礁の生態環境を保全・再生するため、サトウキ ビ畑などの農地からの赤土流出を抑制するハード対策を補完・促進し、流域の環境保全と持続可能な発展を 促すための流域経営システムの導入を提案している。すなわち、流域で行われる様々な社会活動が流域の環 境保全につながり、環境を保全することが流域経済の活性化にもつながるという流域経営のシステムを構築 するのである。ここで、流域経営システムの対象は、八重山地方が日本列島のサンゴ礁の種の供給源である こと、八重山地方の観光マーケットの広がりが全国に及ぶことを考慮し、単なる河川流域だけで捉えるので はなく日本列島の多くを下流受益地とした海流域圈として捉えている。

図-1 は、農業者、観光客、行政、企業、畜産業者、都市住民などのステークホルダーの参画・協㗢による 石垣島の流域経営システムをイメージ化したものである。すなわち、各々のステークホルダーがサンゴ礁保 全・再生に向けたエコプライド（環境保全も経済活動も支える市民の誇り）を醸成しながら、互いの利得を 尊重しつつ、環境保全型農業、新たな産業創生、地場産品購入、寄付、エコッーリズム、サンゴ礁修復活動 などに対して、参画、協働、経営をしている状態を示している。そして、この流域経営システムの資金·情報 提供の動力源であり、コーディネートを担う仕組みとして基金制度を想定している。このようなイメージを 具体化するため、関連する分野の研究者や関係者と意見交換を進めているが、以下では、主に昨年度行って きた様々な研究活動や関係者との意見交換から、石垣島における流域経営の幾つかの可能性について示す。

\section{2-1＼cjkstart観光における可能性}

石垣島の流域経営システムとして観光に着目するのは、観光が石垣島で成長過程にある主要産業であるこ とに加え、(1)観光対象であるサンゴ礁の保全に観光客の参加や協力が望める可能性があること、(2)グリーン ツーリズム、エコッーリズム、ヘルシーツーリズムなどの新たな観光形態とサンゴ礁の保全や農業振興のリ ンクを図机る可能性があること、(3)農産物などの地場産品の消費がとのリンクが望めることなどである。 これらの可能性を検討するには、石垣島の観光客や観光産業の動向を把握することが必要である。

(1)(2)(3)の可能性を示唆する例として、石垣島で大型リゾート施 設を展開するクラブメッド・カビラ（写真-1）の動向を一つの参考 として示す。クラブメッド・カビラは 1999 年に石垣島川平湾に近い 場所に滞在型のリゾートを設置し、石垣島の年間観光客約 70 万人の 7\%弱に当たる約 4 万 5 千人を集客している。注目すべきは、自然散 策やマングローブの植樹活動などを体験する「八重山文化の体験プ ログラム」というオプショナルツアーがリピーターに好評であるこ とである。クラブメッド・カビラのリピーターに、石垣島が美しい 島であって欲しいという意識があり、島の環境保全に寄与する体験

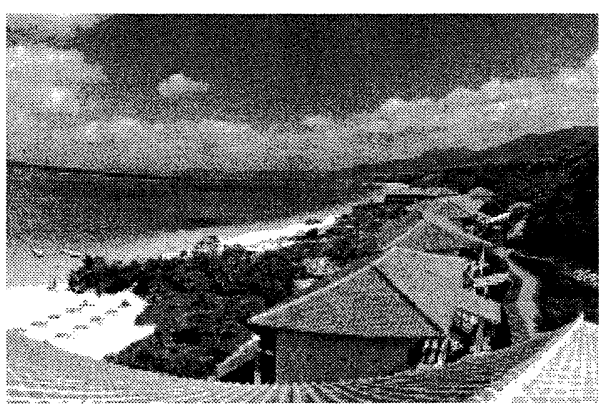

写真-1クラブメッド・カビラ ${ }^{4)}$ 活動への参加希望が多くなっているという。このようなことから、例えば、石垣島のファンやサポーターに よる農業体験ツアー、援農ツアー、サンゴ礁修復ツアーなどへの参加、基金への募金・寄付への協力などの 可能性が示唆される。一方、クラブメッド・カビラでの滞在者の食事は 3 食とも施設内で供給されるが、こ の食材の半分程度を沖縄県内部から調達している。今後は地元農家と無農薬野菜の契約栽培を行うことなど も想定できるということであり、赤土流出の主要な発生面源であるサトウキビ栽培に代替する環境保全型農 業への転換とのリンクも示唆される。

また、(2) こ(3)の可能性を示唆する例として、沖縄県本部町の「も とぶ元気村」の取り組みも注目される ${ }^{3)}$ (写真-2)。この施設の特 徵は、一般的なリゾートとは異なり、健康を増進させるという明確 な目的を持って滞在する健康効用型観光にあり、病院と健康増進施 設、リゾートホテルが統合した構成である。この施設内のレストラ ンの野菜は「やんばる元気野菜」として地元食材がブランド化され ており、健康增進の機能性食品として使われている。この例から、 石垣島の農業振興の形態として、健康保養の機能性食材の供給源と

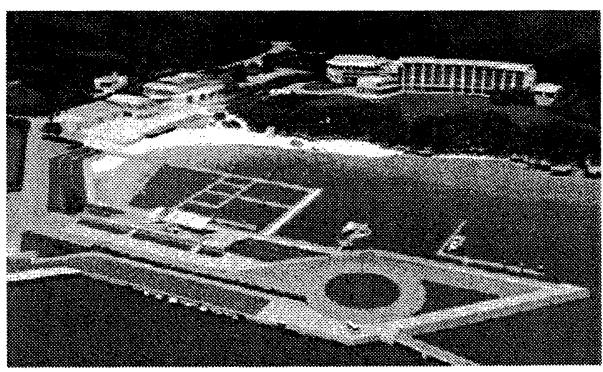

写真-2 もとぶ元気村 ${ }^{5}$ しての可能性が示唆される。すなわち、サトウキビ栽培に代替する高付加価値作物への転換によって、赤土 流出抑制と経済効果が期待できる。すなわち、健康効用型観光という新たな観光形態による地域振興と農業 
振興、環境保全とのリンケージの可能性があるのである。

\section{2-2＼cjkstart農業における可能性}

前節で指摘した通り、観光と農業振興とのリンクの可能性が高いが、ここでは、赤土流出抑制につながる 自立的で持続可能な環境保全型農業のあり方について、幾つかの例をもとにその可能性を示す。

石垣島の農業生産法人有限会社石垣島ファーマーでは、サトウキビ 畑からの赤土流出を抑制するとともに、生産性を高めるカボチャの間 作栽培を試行している。サトウキビを暴風垣として用い、畧間にサト ウキビの葉殼でマルチングをしてカボチャの作付けを行うという農法 である (写真-3)。その効果を実験によって検証した結果、従来のサト ウキビ夏植え栽培法に比べて極めて高い赤土流出抑制効果（95\%減） があり、収益面でも従来のサトウキビ栽培と比べて約 5 倍の収益が見 込めることが確認されている ${ }^{3)}$ 。このようなサトウキビ畑での間作栽

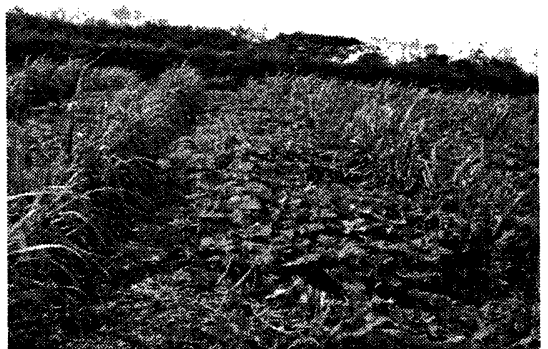

写真-3 カボチャ間作栽培 ${ }^{3)}$ 培は、高い赤土流出抑制効果が期待でき、かつ生産性の高い農法であるため、経営基盤の弱い農家において も取り組める可能性がある。カボチャに限らず様々な作物への応用の可能性もあると考えられる。

また、サトウキビの代替作物として近年、赤土流出抑制効果の高いゲットウも注目されている。ゲットウ はサトウキビに比べ、年中収穫可能であり買付単価も高く、食品以外でも化粧品や消臭剤、建材など、幅広 い分野での商品化が可能ということなどで注目されており、様々な分野での産業化が試行されている。今後 は、ゲットウの商品化のための産業的な仕組みの構築や、適正な価格で買い取りを行うメーカーの創出など の課題があるが、農業振興と環境保全がリンクしうる試みとして可能性がある。

その他、サトウキビ栽培の代替農業としてハウス栽培が考えられる。ハウス栽培は、台風での生産リスク に抗して安定的な収入を確保することができる。石垣市においても高収入を期待できるパパイヤのハウス栽 培方法を研究し、水耕栽培の特許を取得し普及に努めており、自立的で持続可能な代替農業としての可能性 がある。課題としては、農業への将来の不安や農業経営に閉塞感を持っている農業従事者をどのように施設 園芸に転換してもらうかという点である。

一方、新たな農業参入者として建設業者の可能性も指摘される ${ }^{3)}$ 。石垣島の建設業者に対するアンケート 調査の結果では、経営の多角化や新分野への進出に取り組んでいる業者は全体の約 40\%であり、その内の約 $30 \% の$ 業者が経営の多角化の対象として農業をあげている。すなわち、環境保全型農業を企業が経営して行 うという可能性が示唆される。

\section{2-3＼cjkstart環境保全基金に関する可能性}

著者らは流域経営システムの資金・情報提供の動力源であり、コーディネートを担う仕組みとして環境保 全基金を提案しているが、ここでは石垣島周辺で行われている類似の基金制度についてそのリンクの可能性 を示す。著者らが想定している環境保全基金の類似事例としては、「QAB 美ら島募金」「「沖縄県水源基金」、

「美ら海・美ら山募金」などがあげられる。

「QAB 美ら島募金」では、沖縄県のテレビ局のニュース番組を通じて、サンゴ礁保全のためのオニヒトデ 駆除への募金をダイヤル Q2 で募っており、沖縄県域の居住者にとっては容易に参加可能な仕組みである。 しかし、沖縄県以外への情報伝達は困難であることから、沖縄県内だけの活動にとどまっている。「沖縄県水 源基金」は、治水・水資源の安定性確保と水源地域振興などが目的のため、ダム 水源地域ではリンクできる可能性はある。しかし、基金が関係市町村の水道供給 量の負担金から構成され、行政レベルでの活動にとどまっている。一方、「美ら 海・美ら山募金」は、著者らが想定する環境保全基金に最も近く、観光客や市民 を対象として、募金箱で募金を募り、石垣島の環境保全に対する啓発活動や、環 境美化活動、小学生刘象の作文コンクールの開催などを支援している（写真-4）。 また、環境省や石垣市、観光協会とも提携している。しかし、比較的小規模な基 金であり、使途も啓発的な支援にとどまっている。

今後は、流域経営につながる環境保全基金を成立させるため、類似の「美ら海・ 美ら山募金」と意見交換を重ねるとともに、サンゴ礁保全や赤土流出対策を担う 国、沖縄県、石垣市との意見交換、調整を行っていきたいと考える。

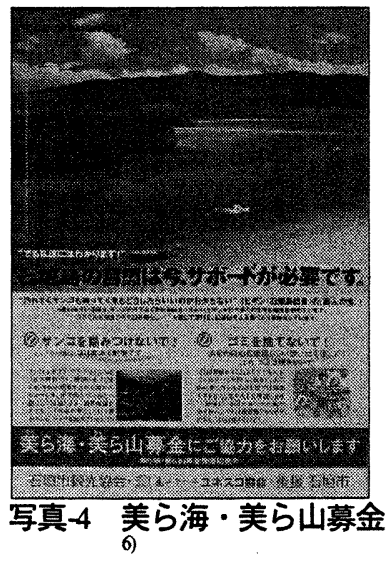




\section{3 流域経営基金の構成要素の検討}

ここでは、石垣島の流域経営に望ましい基金制度 （以下、流域経営基金と称す）を提案するため、著者 ら ${ }^{2)}$ が事例分析によって得た環境保全基金のモデルを もとに、そのインセンティブ要素と使途を検討する。

環境保全基金のモデルのインセンティブ要素は、 (a)保全対象のシンボル化、(b)具体的目標の提示、(c) 有名人・学識者の呼びかけ、(d)意義や趣旨の伝達、(e) 消費活動とのリンク、(f)企業等とのタイアップ、(g)資 源節約の呼びかけ、(h)入金先の多様化、(i)キャンペー ンの展開で構成される。そこで、これらの各インセン ティブ要素の候補を石垣島の資源や課題などから抽出 するとともに、その優劣を評価する項目を試行錯誤的 に設定し、3 段階評価（○:広域レベルに関係するなど 大いに評価できる、○:地域レベルに関係するなどある 程度評価できる、 $\triangle$ :あまりもしくはほとんど評価でき ない）を試みた。その結果を図-2 と表-1に示す。

(a)保全対象のシンボル化については、クマノミ、 マンタ、ナポレオンフィッシュ、ジンベエザメなどの サンゴ礁の保全に関して象徴性が強く、話題性や訴求 性が望め、貴重性や親和性（馴染みやすさ）を有する 海洋生物が高く評価された。

(b)具体的目標の提示については、「サンゴ礁の回 復量」や「増殖・移植サンゴの量」が、サンゴ礁保全 や赤土流出抑制などの表現性に優れ、定量的で計量可 能であることに加え、話題性や訴求性も望めることが 高く評価された。すなわち、サンゴ礁の回復の目標値 や移植・增殖の目標值を定量的に提示するとともに、 その進行状況を計量して募金者や寄付者に示すことが 効果的と考えられる。

(c)有名人・学識者の呼びかけについては、その協 力可能性や、表現性、知名度、訴求性などの項目で八 重山地方出身の歌手が高い評価となり、今後の協力呼 びかけ対象である。(d)意義や趣旨の伝達については、

「サンゴ礁の危機的状況」や、「赤土流出の影響」、「サ ンゴ礁の供給源」「募金・寄付の効果」が、表現性、 話題性、訴求性に優れるとともに、国民の行動を喚起 しうる内容しして評価された。すなわち、意義や主旨 を伝達するため、上記の事項をもとに分かりやすいス トーリーを組み立てていくことが重要である。
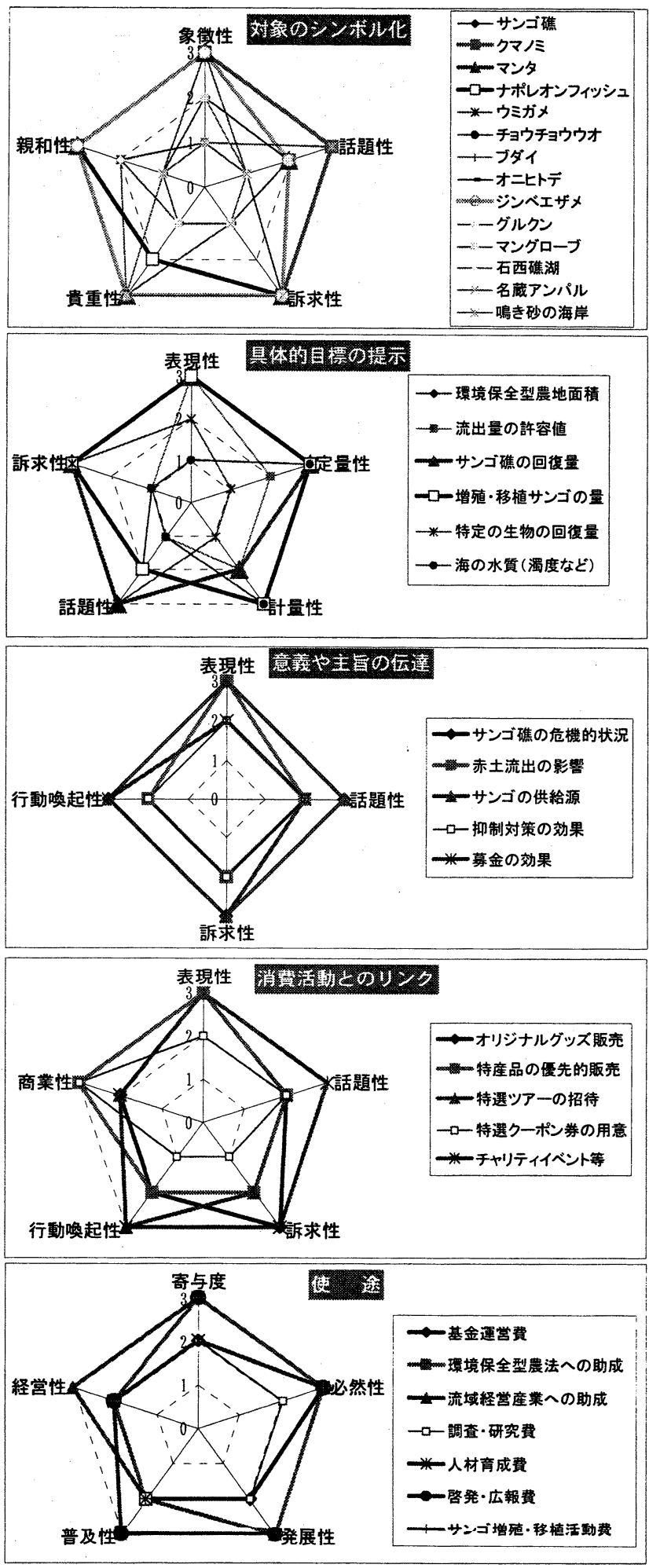

図-2 基金制度の構成要素の評価結果(一部)

(e)消費活動とのリンクについては、オリジナルグッズの販売、特産品の優先的販売、特選ツアーの招待、 チヤリティイベントの開催などが、その表現性、話題性、訴求性、行動喚起性、商業性などの項目において 高い評価となった。(f)企業等とのタイアップは、航空会社、観光業者、マスコミ等関連企業が、サンゴ礁保 全や赤対流出抑制の流域経営との関係性や、企業等の利得との整合性において優れ、話題性や貢献性、発展 性などの項目についても望めることが評価された。その他、(g)資源節約の呼びかけについては減堆肥とのマ ッチング、(h)入金先の多様化ではインターネットの活用、(i)キャンペーンの展開では航空会社や観光施設、 著名人との連携キャンペーンを展開することが高い評価となった。 
一方、基金の使途については、サンゴ礁 や赤土流出抑制への寄与度、基金適用の必 然性、発展性、普及性、経営性などの観点 から、「赤土流出抑制につながる環境保全 型農法への助成」、流域経営を促す産業振 興への助成」が重要であると評価された。 加えて、基金の運営費、人材育成費、啓発・ 広報費、サンゴ増殖・移植の活動費に充当 させることが重要と評価された。

これらの評価結果をもとに石垣島の流 域経営基金の体系を図-3 に示す。今後は、 募金者や寄付者と双方向の交流・連携を促 すフィードバック要素についても、マーケ ティング調査により検討を行う予定である。 そして、次第に流域経営基金の具体像を明 らかにしながら、その具体化に向け、関係 機関と調整を行う予定である。また、ここ で検討した基金制度のインセンティブ要素 や使途の評価項目は、他の環境保全基金の 制度設計についても適用可能である。 表-1＼cjkstart基金制度の構成要素の評価項目と評価結果

\begin{tabular}{|c|c|c|}
\hline 構成要素 & 評価項目 & 評価が高かった内容 \\
\hline 対象のシンボル化 & $\begin{array}{l}\text { 象徵性、話題性、訴求 } \\
\text { 性、貴重性、親和性 }\end{array}$ & $\begin{array}{l}\text { クマノミ、マンタ、ナポレオン } \\
\text { フィツシュ、ジンベエザメ }\end{array}$ \\
\hline 具体的目標の提示 & $\begin{array}{l}\text { 表現性、定量性、計量 } \\
\text { 性、話題性、訴求性 }\end{array}$ & $\begin{array}{l}\text { サンゴ礁の回復量、増殖· } \\
\text { 移植サゴの量 }\end{array}$ \\
\hline $\begin{array}{l}\text { 有名人・著名人の } \\
\text { 呼びかけ }\end{array}$ & $\begin{array}{l}\text { 協力可能性、表現性、 } \\
\text { 知名度、訴求性 }\end{array}$ & 歌手 $N$ 、歌手B \\
\hline 意義や主旨の伝達 & $\begin{array}{l}\text { 表現性、話題性、訴求 } \\
\text { 性、行動喚起性 }\end{array}$ & $\begin{array}{l}\text { サンゴ礁の危機的状況、赤 } \\
\text { 土流出の影響、サンゴの供 } \\
\text { 給源、募金の効果 }\end{array}$ \\
\hline $\begin{array}{l}\text { 消費活動とのリン } \\
\text { 地 }\end{array}$ & $\begin{array}{l}\text { 表現性、話題性、訴求 } \\
\text { 性、行動喚起性、商業 } \\
\text { 性 }\end{array}$ & $\begin{array}{l}\text { オリジナルグッズ販売、特 } \\
\text { 産品の優先販売、と癖ヅ } \\
\text { 一の招待、チヤリテイイベ } \\
\text { ト }\end{array}$ \\
\hline 企業とのタイアップ & $\begin{array}{l}\text { 関係性、利得性、話題 } \\
\text { 性、貢献性、発展性 }\end{array}$ & $\begin{array}{l}\text { 航空会社、観光業者、マス } \\
\text { コミ関連企業 }\end{array}$ \\
\hline $\begin{array}{l}\text { 資源等節約の呼び } \\
\text { かけ }\end{array}$ & $\begin{array}{l}\text { 閏係性、話題性、貢献 } \\
\text { 性、利得性、計量性 }\end{array}$ & 現堆肥とのマッチング \\
\hline 入金先の多様化 & $\begin{array}{l}\text { 普及性、容易性、集金 } \\
\text { 性、話題性 }\end{array}$ & インターネット \\
\hline キャンペーン展開 & $\begin{array}{l}\text { 話題性、集金性、発展 } \\
\text { 性、普及性、継続性 }\end{array}$ & $\begin{array}{l}\text { 航空会社、観光施設·著名 } \\
\text { 人との連携キャンペーン等 }\end{array}$ \\
\hline 使途 & $\begin{array}{l}\text { 奇与度,必然性、発展 } \\
\text { 性、普及性、経営性 }\end{array}$ & 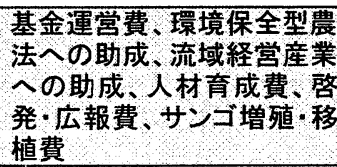 \\
\hline
\end{tabular}

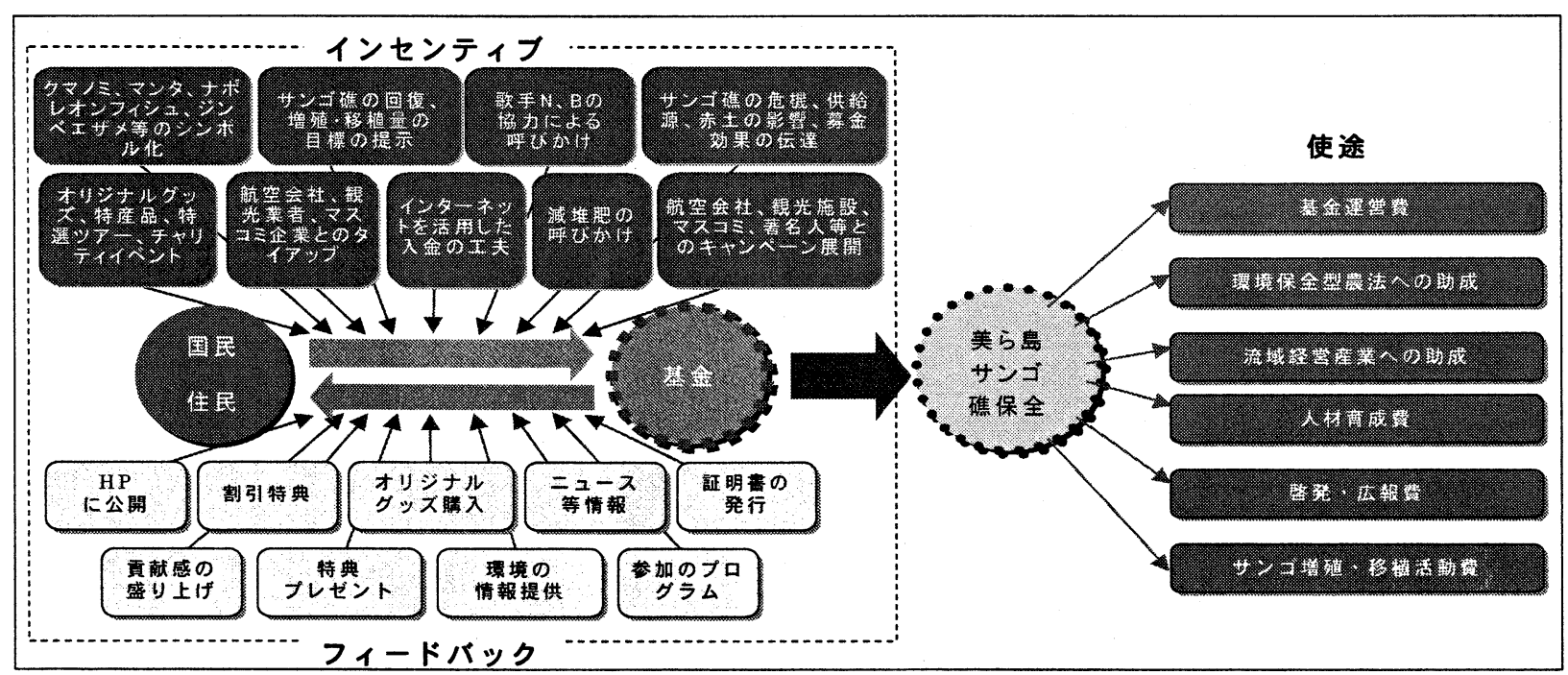

図-3 石垣島における流域経営基金の構成要素

\section{4 政策提言・実現のための取組み}

本研究は、ハード面での赤土流出抑制対策やサンゴ礁修復対策の研究開発とともに進めている(このよう な研究グループを「ハード班」、流域経営に関する研究グループを「ソフト班」と称している)。このハード 班、ソフト班は研究面での情報交換、意見交換を密に行いながら進行させており、目標とするところは、沖 縄地方の赤土流出抑制の問題解決に研究成果が活かされるように政策提言を行うことである。そして、それ らの政策内容が実社会において、適切に具現化されることである。

しかしながら、本研究のように、多種多様な分野の研究者が協働して問題解決を志向した研究活動を行う 場合、全ての研究が一定の成果を得てから政策提言を行うには時間を要し、その間にも問題が進行する、行 政施策の検討が進渉するなど、その政策実現の期を逸する可能性が大きい。また、流域経営のようなステー クホルダーが多様で広範囲に及ぶテーマでは、主要な関係者の意見交換を図りながら、研究が実現象や実社 会に適合するように適宙軌道修正をしながら進行させていくここが望ましい。さらには、そUような意見交 換の中から、ステークホルダーの合意形成と連携・協働関係を醸成していくことも重要と考える。そのため、 
本研究では、図-4に示すように様々な 行政機関、関係団体、NPO、企業等に 働きかけながら研究を進めている。

年に 2 回行うハード班とソフト班 の全体研究交流会では、環境省や国土 交通省などの国の機関、沖縄県農林水 産部、石垣市農林水産部などの行政機 関に参画してもらい、研究成果に対し て様々に情報交換、意見交換を重ねて いる。また、年に 4 回程度開催するり フト班の研究交流会では、NPO や企業 等をゲストスピーカーとして招いて意 見交換を進めている。

さらに、行政が行う検討会や計画策

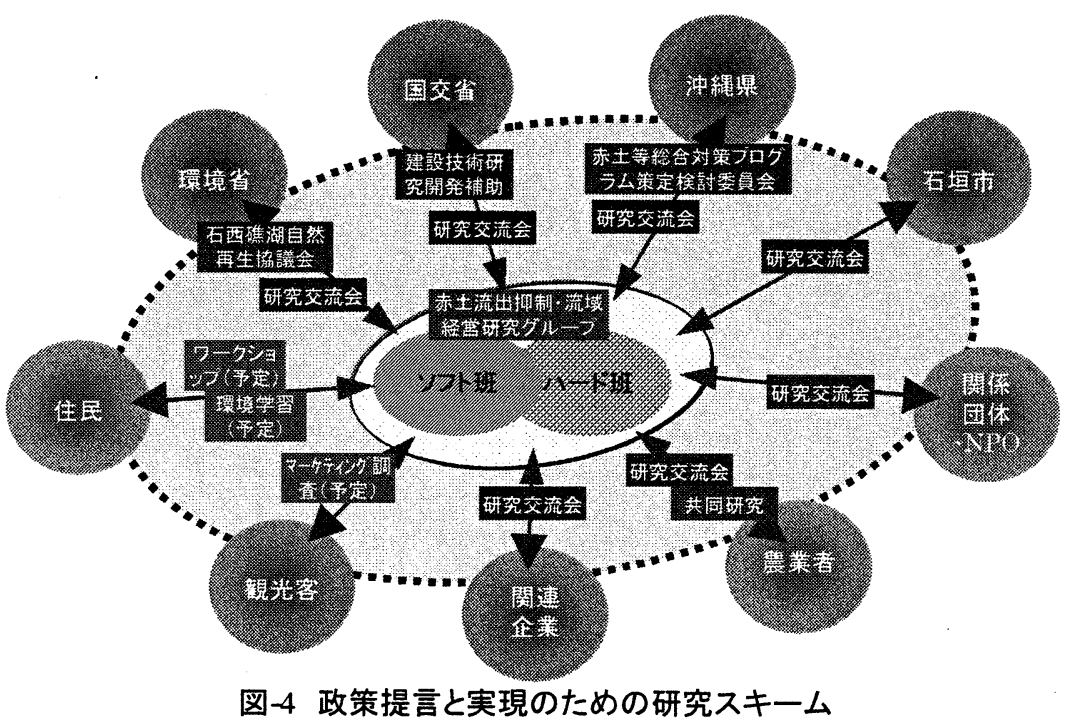

定にも積極的に参画している。環境省が進める「石西礁湖自然再生事業」に対しては、サンゴ礁修復の研究 者である岡本峰雄氏（東京海洋大学助教授）が専門委員として参画し、サンゴ礁修復の手法 ${ }^{6}$ について提言 してその試行を行うとともに、流域経営に関してタイムリーで具体的な提言を行うため、「石西礁湖自然再生 推進協議会」のメンバーとして共著者の惠小百合（江戸川大学教授）が公募で参画している。また、沖縄県 農林水産部が検討を進めている「赤土等総合対策プログラム策定検討委員会」においては、仲地宗俊氏（琉 球大学教授）が委員長として、惠小百合が委員として参画し農地対策プログラムの検討を進めている。

今後は、地域住民や児童に対して地域ワークショップの開催や環境学習の試行を、観光客に対してはマー ケティング調査などを予定している。

\section{5 おわりに}

本稿では、沖縄地方の赤土流出問題の解決に向けて、流域経営システムと基金制度の構成と可能性につい て、政策提言・実現に向けた研究を進めている中から、(1)石垣島における流域経営システムの可能性、(2) 基金制度の構成要素と評価、(3)政策提言・実現のための取組みについて報告した。今後のソフト班としての 研究課題としては、(a)マーケティング調査による流域経営システムの可能性検討と基金制度の設計、(b) 流 域経営のための農法の開発と普及促進策の検討、(c)流域経営のための産業クラスターの可能性検討、(d)地域 住民との意見交換の枠組み検討と政策実現に向けた関倸の醸成などを予定している。沖縄地方の赤土流出問 題が多様なステークホルダーの協働によって発展的に解決され、持続可能な産業振興が図られるよう、今後 も精力的な研究に取り組んでいきたい。最後になったが、本研究は国土交通省平成 17 年度建設技術研究開発 費補助事業の研究助成を受けていることを記すとともに、本研究の害行にあたり様々な意見交換を頂いた全 ての研究関係者に謝意を表すものである。

\section{参考文献：}

1) 例えば、大澤和敏・山口悟司・池田駿介・高椋恵: 農地における土砂流出抑制対策の比較試験, 水工学論文集, 49 , pp.1099-1104, 2005.

2) 宮本善和・成瀬研治·松下潤·惠小百合:沖縄地方の赤土流出防止に向けた流域経営システムに関する研究一基金制度の 視点から一, 第 13 回地球環境シンポジウム講演論文集, pp.65-70, 2005.

3）松下潤他：沖縄における流域経営と赤土流出抑制システムの促進方策に関する研究,国土交通省平成 17 年度建設技 術研究開発費補助事業研究報告, 2006.

4) クラブメッド:沖縄石垣島クラブメッド・カビラパンレット

5) もとぶ元気村:もとぶ元気村パンフレット

6) [特許]発明者: 岡本峰雄・古島靖夫·野島哲, サンゴ礁の人工増殖具及び増殖方法, 特許第 3530832 号 2004 年 3 月 5 日, 特許権者:海洋科学技術センター. 